\title{
UPPER CARAŞ RIVER (DANUBE WATERSHED) FISH POPULATIONS FRAGMENTATION - TECHNICAL REHABILITATION PROPOSAL
}

\author{
Răzvan VOICU *, Doru BĂNĂDUC **, Lee Jason BAUMGARTNER ***, \\ Liliana VOICU * and Angela CURTEAN-B $\breve{A N A D U C} * *$
}

\begin{abstract}
* National Institute of Hydrology and Water Management, București-Ploiești Street 97, București, Romania, RO-013686, rzvnvoicu@yahoo.com, lilianavoicu80@gmail.com

** "Lucian Blaga" University of Sibiu, Faculty of Sciences, Dr. Ion Raţiu Street 5-7, Sibiu, Sibiu County, Romania, RO-550012, ad.banaduc@yahoo.com, angela.banaduc@ulbsibiu.ro

*** Charles Stuart University, Institute for Land, Water and Society, P.O. Box 789, Albury, New South Wales, Australia, lbaumgartner@csu.edu.au
\end{abstract}

DOI: 10.1515/trser-2018-0006

KEYWORDS: Site of Community Importance, Caraş Gorge, stream, fish, river continuum rehabilitation.

\section{ABSTRACT}

We propose a technical solution for fish movement based on the flow of water over a spill threshold. Such barriers are common in the Danube system. The proposed system has a range of operating components which are easily detachable from the spill threshold, are resistant to corrosion and will not harm the fish. In fact, if designed to complement swimming abilities of target fish, it should provide adequate passage for both adults and juveniles. If implemented correctly, the design may offer a solution to help displaced fish recolonize upstream habitats.

RÉSUMÉ: La fragmentation des populations piscicoles du Caraş Supérieur (bassin du Danube) - proposition technique de réhabilitation.

Nous avons proposé une solution technique pour le déplacement des poissons à l'aide de l'écoulement de l'eau au-dessus d'un déversoir. Des tells barrières sont fréquents dans le système hydrographique du Danube. Le système proposé est formé d'une série de composantes opérationnelles facilement détachables du déversoir, résistant à la corrosion et dont la forme ne blesse pas les poissons. En fait, s’il est projeté la capacité de nage des poisson cible aidant, il devrait fournir un passage adéquate pour les adultes ainsi que pour les juvéniles. Si correctement implémenté, le design pout fournir une solution aidant les poisson délocalisées à recoloniser les habitats en amont.

REZUMAT: Fragmentarea populațiilor piscicole de pe Carașul superior (Bazinul Dunării) - propunere tehnică de reabilitare.

Am propus o soluție tehnică pentru deplasarea peștilor cu ajutorul fluxului apei peste un prag deversor. Astfel de bariere sunt frecvent întâlnite în bazinul Dunării. Sistemul propus are o serie de componente de operare care se pot demonta ușor de pe pragul deversor, sunt rezistente la coroziune, iar forma lor nu rănește peștii. Mai mult, dacă este proiectat pentru a veni în întâmpinarea capacității naturale de a înota a peştilor țintă, ar trebui să permită trecerea în condiții adecvate, atât pentru adulți, cât și pentru juvenili. Dacă se implementează în mod correct, proiectul poate fi o soluție pentru a permite recolonizarea habitatelor din amonte de către peştii dislocaţi din habitat. 


\section{INTRODUCTION}

Longitudinal and transversal connectivity is essential to ecological functioning in freshwater ecosystems (Aadland 1993, 2010; Barbosa et al., 2001; Sedeno-Diaz and Lopez-Lopez, 2009; Sommerwerk et al., 2010; Bănăduc et al., 2016; Lenhardt et al., 2016). But the construction of dams and weirs can act as migration barriers which prevent organisms, such as fish, to reach critical habitat areas. Fish migration barriers are a main cause of fish communities decline from fragmentation of habitats due to barriers which do not allow downstream fish to move upstream. Employing solutions which facilitate these important migrations are essential, but are not consistently applied. (Larinier, 1983; Katopodis, 1990; O’Doherty, 2009)

Restoring the longitudinal connectivity of the rivers is an essential mechanism to rehabilitate watercourses (Fischer and Cyffka, 2014; Voicu and Breţcan, 2014) and should be a priority for decision-making to protect lotic ecosystems (Kemp and O'Hanley, 2010; Voicu et al., 2015; McKay et al., 2016). Transversal works which lead to the interruption of longitudinal connectivity of rivers is an important issue in Europe (Kay and Voicu, 2013). All river managers must keep or restore longitudinal connectivity in accordance with the Water Framework Directive (Voicu and Merten, 2014). As such, developing new solutions for fish mobility systems over hydrotechnical constructions and improving existing ones is an important priority. Many of such old systems need to be improved, and new designs deployed, in order to help recover fish communities across Europe (Baxter, 1977; Bunn and Arthington, 2002; Voicu and Baki, 2017).

Salmonidae species are well represented in the Romanian Carpathians fauna (six species) in the wild and farmed in fish farms. But weirs and migration barriers are limiting the ability for salmonids to expand distribution throughout Danube tributaries. In spite of this general situation, human activities often fragment their lotic habitats, so that imbreeding and genetic isolation might occur in the wild isolated populations. (Popa et al., 2013, 2016; Nechifor et al., 2017). Solutions need to be found that enable fish to expand their current distribution, facilitate the movements of all size classes and help to overcome migration barriers which cannot be removed.

Caraş River, a tributary of the Danube River, rises on the western side of the Semenic Mountains at arround $700 \mathrm{~m}$. The surface of the Caraş Basin on the territory of Romania is $1,118 \mathrm{~km}^{2}$ and the length of the river is $80 \mathrm{~km}$. The upper Caras Basin is characterized by, limestone crossed areas, forming wild gorges with accentuated slopes. The specific multiannual average flow varies between $20 \mathrm{l} / \mathrm{s} \mathrm{km}$ in the high mountain range, and below $20 \mathrm{l} / \mathrm{s} \mathrm{km}$, up to $7.0 \mathrm{~km}^{2}$. There are episodes of very high floods which can displace fish downstream over existing migration barriers. In contrast winter ice-bridges form in 10-15\% of winters but only last for a few days (Posea, 1982; Ghinea, 2002). There are many barriers within the Caraş River system which presently preclude the free passage of Salmonidae species from downstream to upstream reaches. 


\section{FISH POPULATION IN THE CARAS RIVER}

The fish fauna of the river Carass was described more than a half of the century ago by Bănărescu in 1964. The species present in this river in the past were: Salmo trutta fario (in its upper course till Caraşova locality), Esox lucius (from Cacova locality till the Caraş River confluence with the Danube River), Rutilus rutilus (in the Oraviţa area), Phoxinus phoxinus (till to the Cacoveni locality), Tinca tinca (lower course), Scardinius erythrophthalmus (Oraviţa area), Squalius cephalus (Oraviţa, from Cacoveni), Alburnus alburnus (Oraviţa area), Alburnoides bipunctatus (from upstream Caraşova), Blicca bjoerkna (Oraviţa area), Chondrostoma nasus (from Gârlişte), Rhodeus sericeus (from Caraşova), Gobio gobio (from Caraşova), Romanogobio albipinnatus (from Cacoveni), Romanogobio kessleri (at Cacoveni), Barbus barbus (from Goruia), Barbus meridionalis (from upstream Caraşova), Cyprinus carpio (in Oraviţa area), Carassius carassius (lower course), Barbatula barbatula (from upstream Caraşova to Cacoveni), Misgurnus fosilis (Oraviţa area), Cobitis taenia (from Cacoveni to the confluence with Danube River), Sabanejewia balcanica (from Caraşova), Silurus glanis (in its lowest part), Lota lota (Oraviţa area), Perca fluviatilis (downstream of Cacoveni), Sander lucioperca (Oraviţa area) (Bănărescu, 1964).

The Caraş River fish fauna has significantly changed both due to the appearance of new species including invasive ones and the restriction of some of the native species distribution area, also decreases in the abundance of some species of economic and/or conservation interest. The relatively numerous thresholds and dams without fish passage, pollution, the emergence of some invasive species and poaching have led to these fisheries changes.

The Salmo trutta fario population in the Caraş River is characterised by low catches which are dominated by adults (under $5 \%$ juveniles). Colonisation of the Caraş River from other streams and rivers is prevented by numerous concrete thresholds and dams, including a series of three downstream of the lower limit of this reach. These obstacles isolate this population preventing upstream colonisation by individuals displaced by floods into downstream unappropriate habitats. The resultant situation is an obvious age class imbalance.

Three concrete thresholds without fish passage presently exist downstream of the Caraş Gorges. These sites would substantially benefit from improved fish passage. Salmonid individuals washed downstream of these barriers are presently unable to move back upstream, and suffer there both the trophic competition of other fish species (the dominant Barbus meridionalis, Alburnoides bipunctatus and Phoxinus phoxinus) and human impact effects. Just two-three km downstream the fish fauna composition (Barbus meridionalis, Alburnoides bipunctatus, Orthrias barbatulus, Sabanejewia aurata balcanica, Gobio gobio, Rhodeus sericeus amarus, Phoxinus phoxinus, and Squalius cephalus) reveal changings in the lotic habitats which are no more appropriate for salmonids. This study aims to propose some innovative fish passage solutions that could potentially assist salmonid movement in this river reach. 


\section{BARRIERS TO FISH MMOVEMENT}

The first discharge sill is upstream of the other two discharge sills in the existing three series (Fig. 2). It is characterised by a waterfall about 3.5 meters high, about 15 meters long and a crown width about 1.2 meters. At approximately 1.5 meters of the crown inside the discharge sill are two pipes each with $40 \mathrm{~cm}$ diameter where flowing are about one $\mathrm{m}^{3} / \mathrm{s}$ for each pipe (Fig. 3). River slope is roughly 20\%. This discharge sill is the first obstacle for Salmo trutta fario (Fig. 1a, b) from upstream to downstream, and downstream of the first discharge sill (1). If fish were able to somehow ascend this barrier, then two further upstream barriers must be ascended to reach optimal habitat.

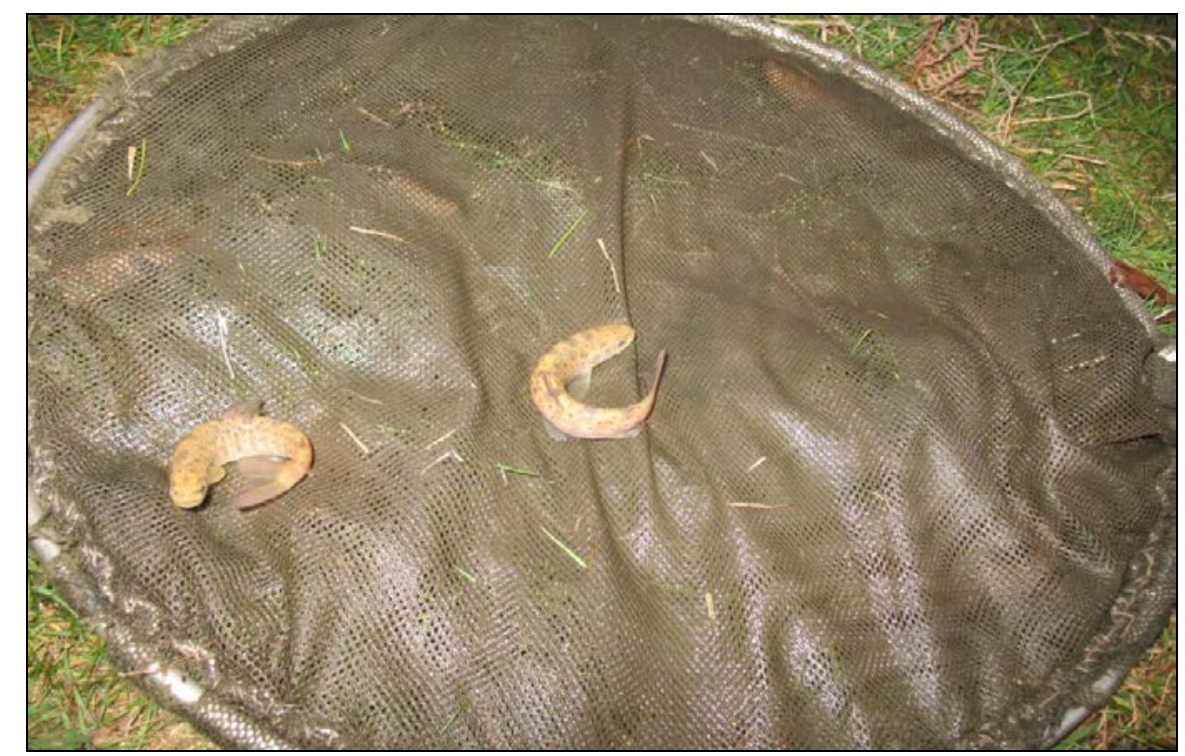

Figure 1a: Salmo trutta fario individuals in the researched area.

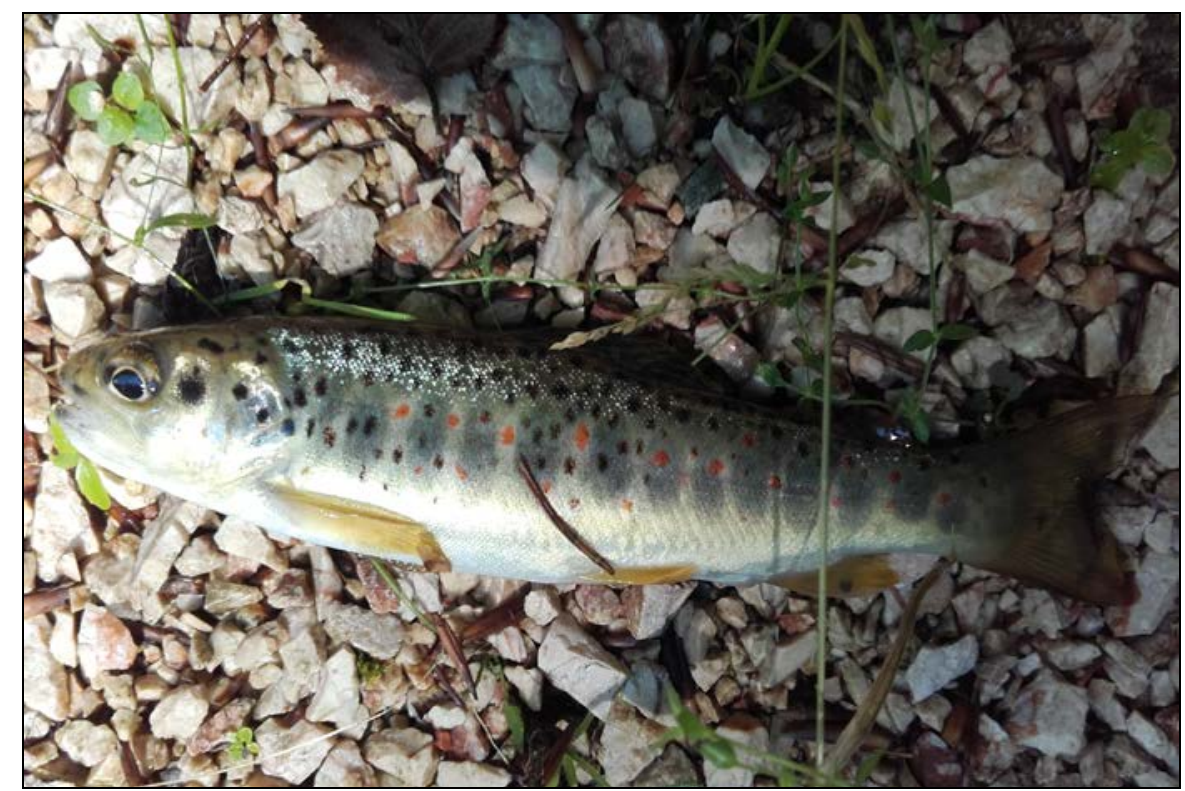

Figure 1a: Salmo trutta fario individuals in the researched area. 


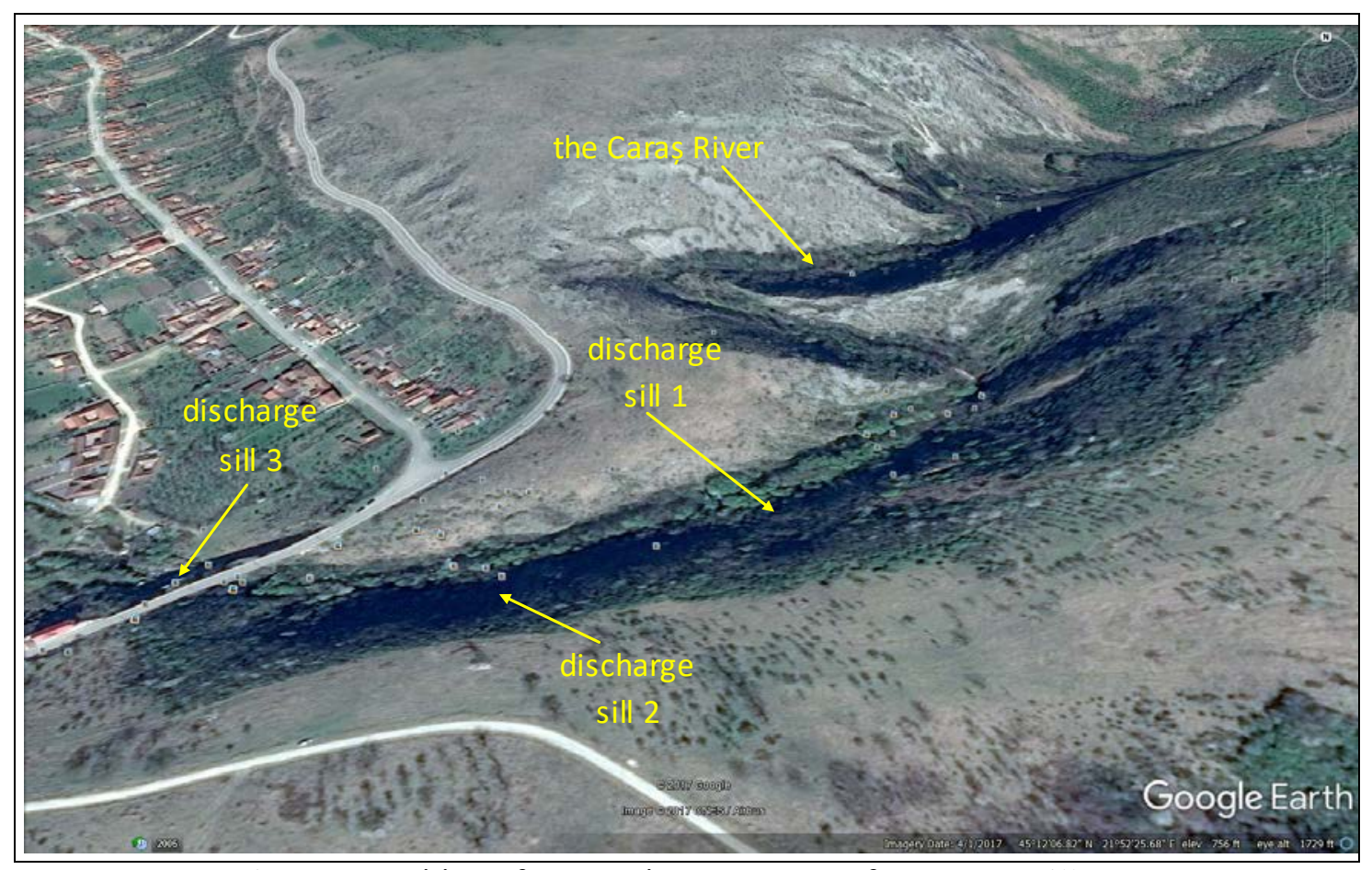

Figure 2: Position of Caraș River upstream of Carașova Village.

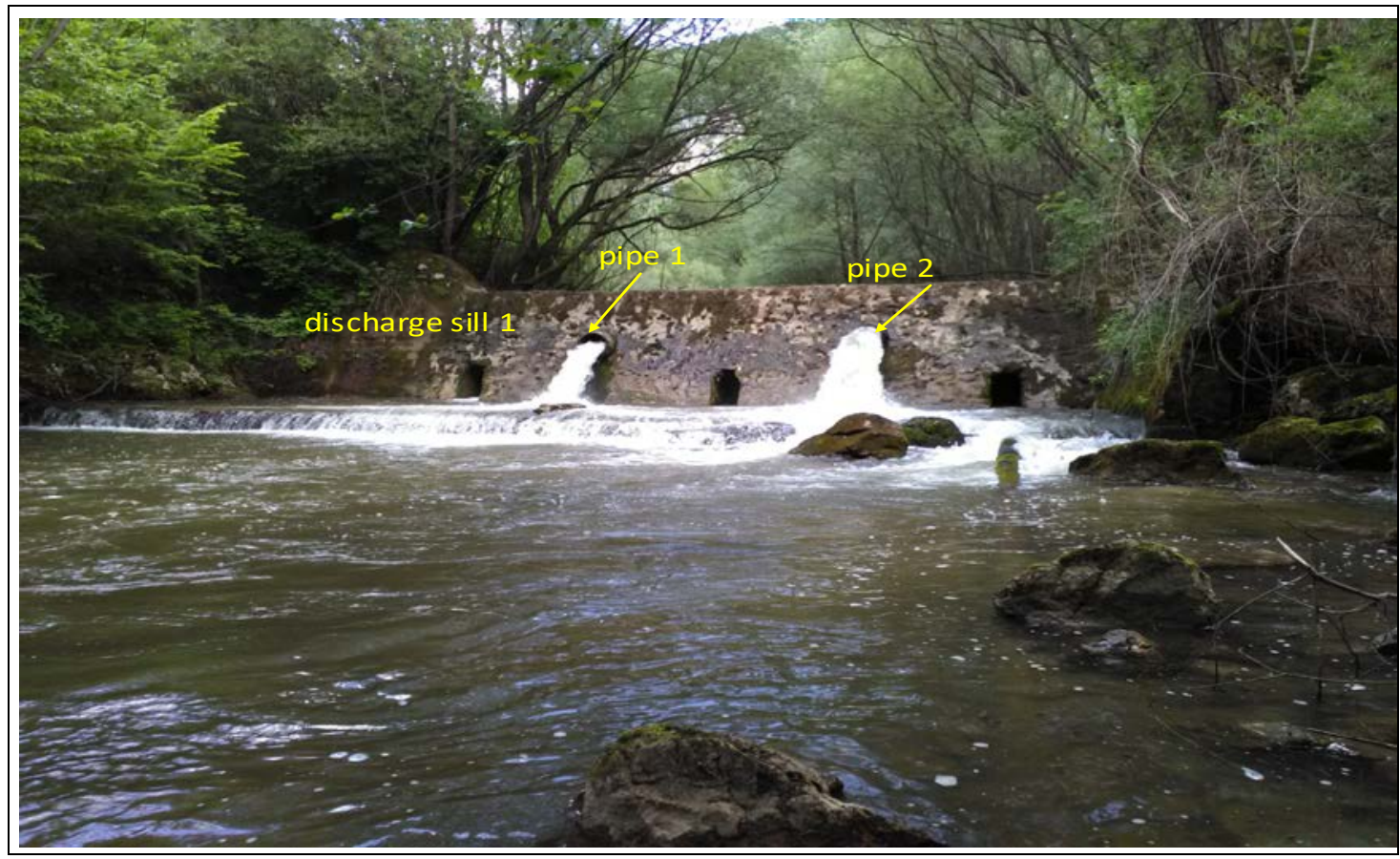

Figure 3: The first discharge sill threshold and the positioning of the two pipes. 


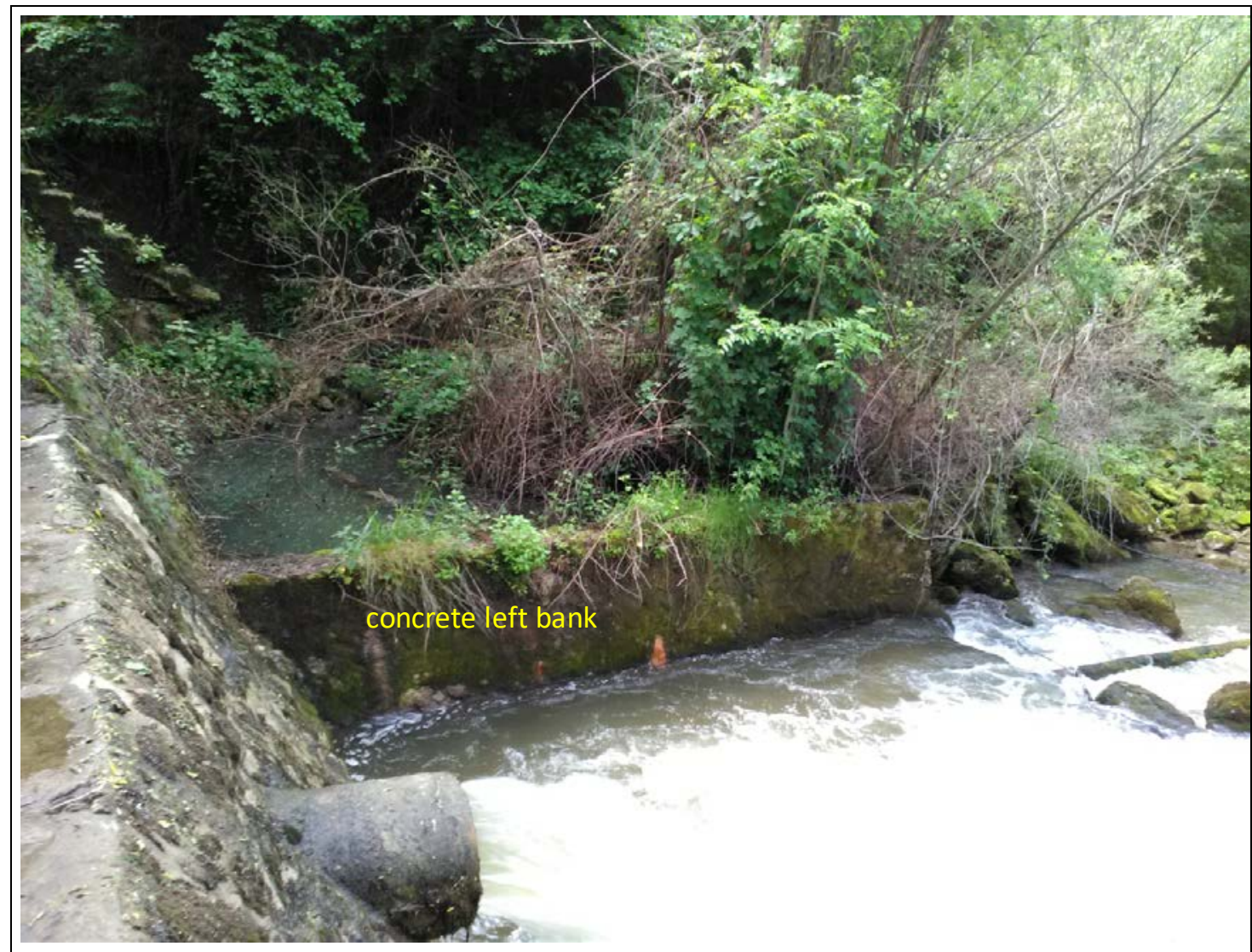

Figure 4: Concrete left bank of the Caraș River upstream of the discharge sill 1.

\section{ACHIEVING FISH PASSAGE AT THESE SITES}

It is not possible to remove the three barriers on the Caraș River. Nor is it possible to install a fully engineered technical fishway. We subsequently propose a non-technical fish passage retrofitting option. This will ensure that the existing threshold remains largely in-tact, whilst fish passage is improved.

The first step in achieving a retrofit fish pas at these sites will be to facilitate a breach in the weir face (Figs. 5 and 6). This is essential for water flow into the structure to allow fish to pass whilst taking advantage of the existing operating head.

The breach must have a minimum height of $60 \mathrm{~cm}$, width $40 \mathrm{~cm}$ and be higher than the two water pipes. We then propose fixing a semi-rectangular concrete basin $(10 \mathrm{~cm}$ thick concrete sheet pile) onto the discharge sill. This basin will have two trapezoidal surfaces and be fixed onto the discharge sill 1 and supported by a concrete pillar fixed in the river bed (Fig. 7). Above the semi-rectangular concrete basin will be fixed a transparent and glass sheet pile to protect this basin. An attraction discharge will enter the basin through the two pipes. These works will essentially form a channel that is retrofitted to the weir crest that will facilitate upstream fish movements. The next challenge is to ensure that flows within the channel will complement target species swimming abilities. 
From the parallelpiped basin crenel it will be necessary to fit a rectangular channel (module M1) with the same dimensions as the crenel. To maximise cost-effectiveness without compromising function, this rectangular channel (module M1) could be constructed from galvanized metal sheets of $1.5 \mathrm{~cm}$ thickness (for structural strength). Ensuring that the channel slope does not exceed that of the river channel aims to match local hydraulics. The challenge will be to ensure that sufficient resting pools are included to enable fish to conserve energy whilst they ascend the structure. The entire sctructure would be fixed to the threshold 1 by means of metal bars with dowels and at the bottom of the M1 module. Concrete bars could be included where additional strength is required (Fig. 9). High-strength, transparent glass could be included along the full length of module 1 should there be a need to inspect fish as they perform upstream migrations.

Upon completion, the channel could be extended over the concrete left bank and will connect to a rectangular parallelpiped basin 2 fixed on the concrete left bank (Fig. 10).

To achieve a fish free movement system for the begining, should be made a breach on the discharge sill 1 at approximately three $m$ from the right bank (Figs. 5 and 6 ).

Breach has a height of $60 \mathrm{~cm}$, width $40 \mathrm{~cm}$ and it is higher than the two water pipes. In front of this breach realization on the 1st discharge sill is fixed on the discharge sill a semi-rectangular concrete basin (10 cm thick concrete sheet pile). This basin will have two trapezoidal surfaces that will fit perfectly on the discharge sill 1 . This basin will also be supported by a concrete pillar fixed in the river bed (Fig. 7). Above the semi-rectangular concrete basin will be fixed a transparent and very resistant glass sheet pile that protects this basin. Breach will take over some of the flow that flowing through the two pipes.

From the parallelepiped basin crenel start a rectangular channel (module M1) with the same dimensions as the crenel. This rectangular channel (module M1) consists of galvanized metal sheets of $1.5 \mathrm{~cm}$ thickness and with a slope that can be to times smaller than the slope of the river. At the top of the M1 module will be fixed to the threshold 1 by means of metal bars with dowels and at the bottom of the M1 module with the help of some concrete bars (Fig. 9). Above this rectangular canal will be placed a high-strength, transparent glass with the length of that of the module 1 .

The channel will extend over the concrete left bank and will connect to a rectangular parallelepiped basin 2 fixed on the concrete left bank (Fig. 10). 


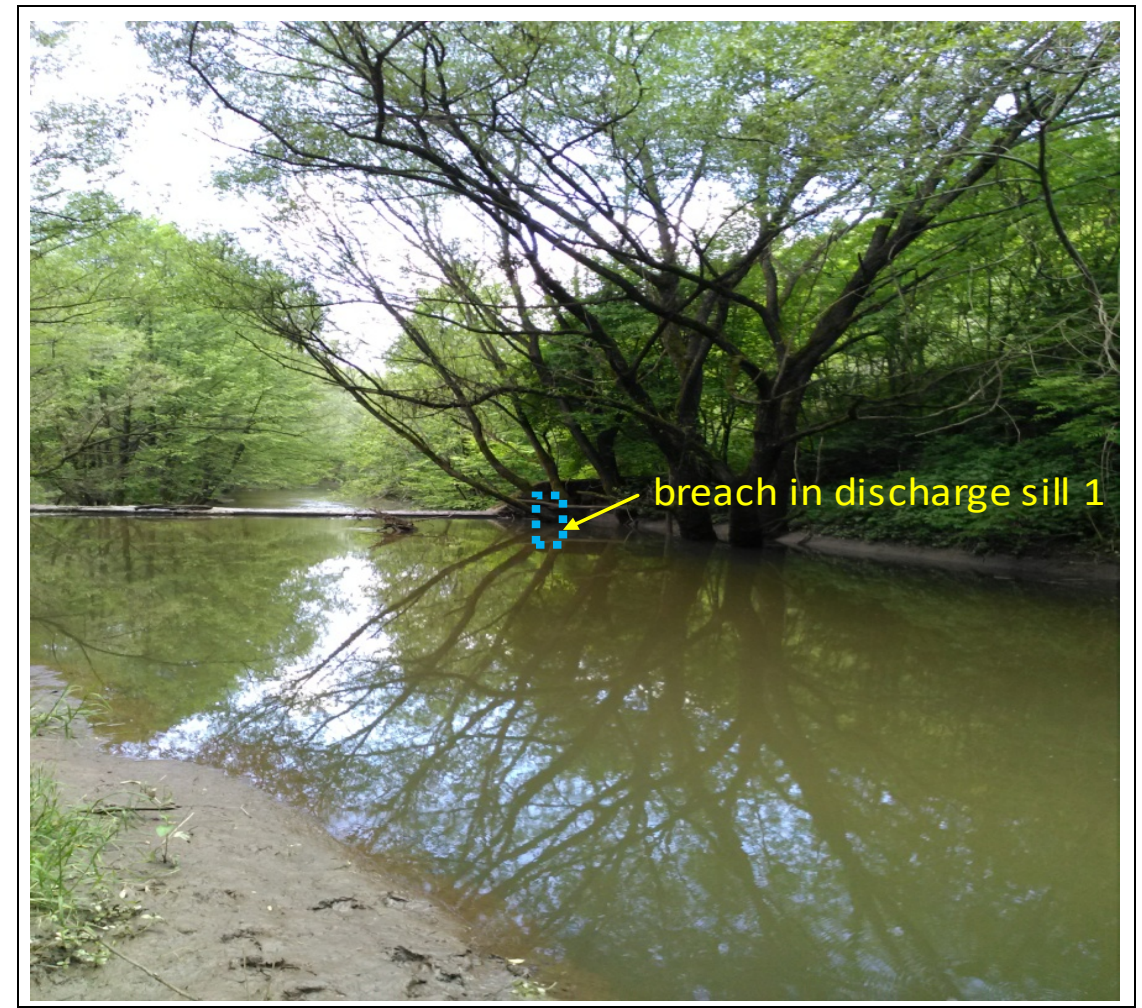

Figure 5: Upward view of the breach.

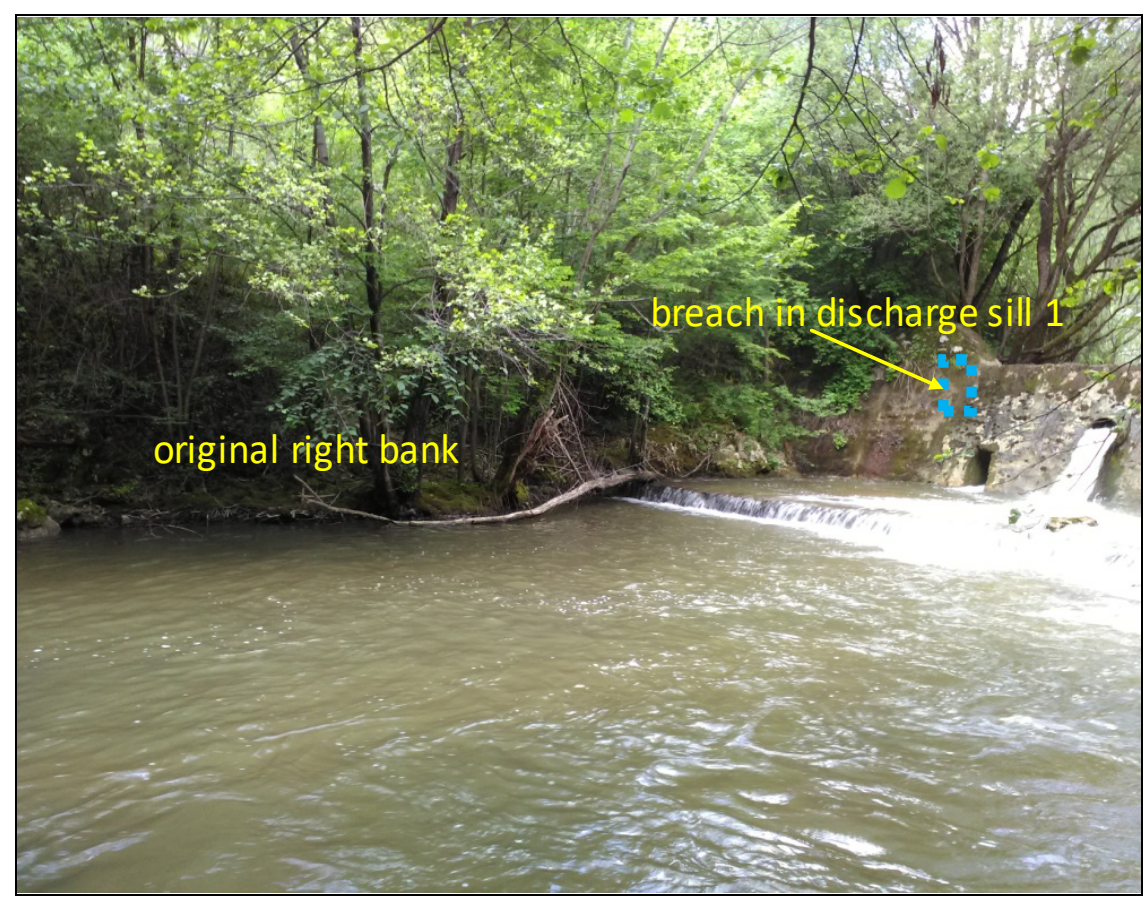

Figure 6: Downstream view of the breach. 


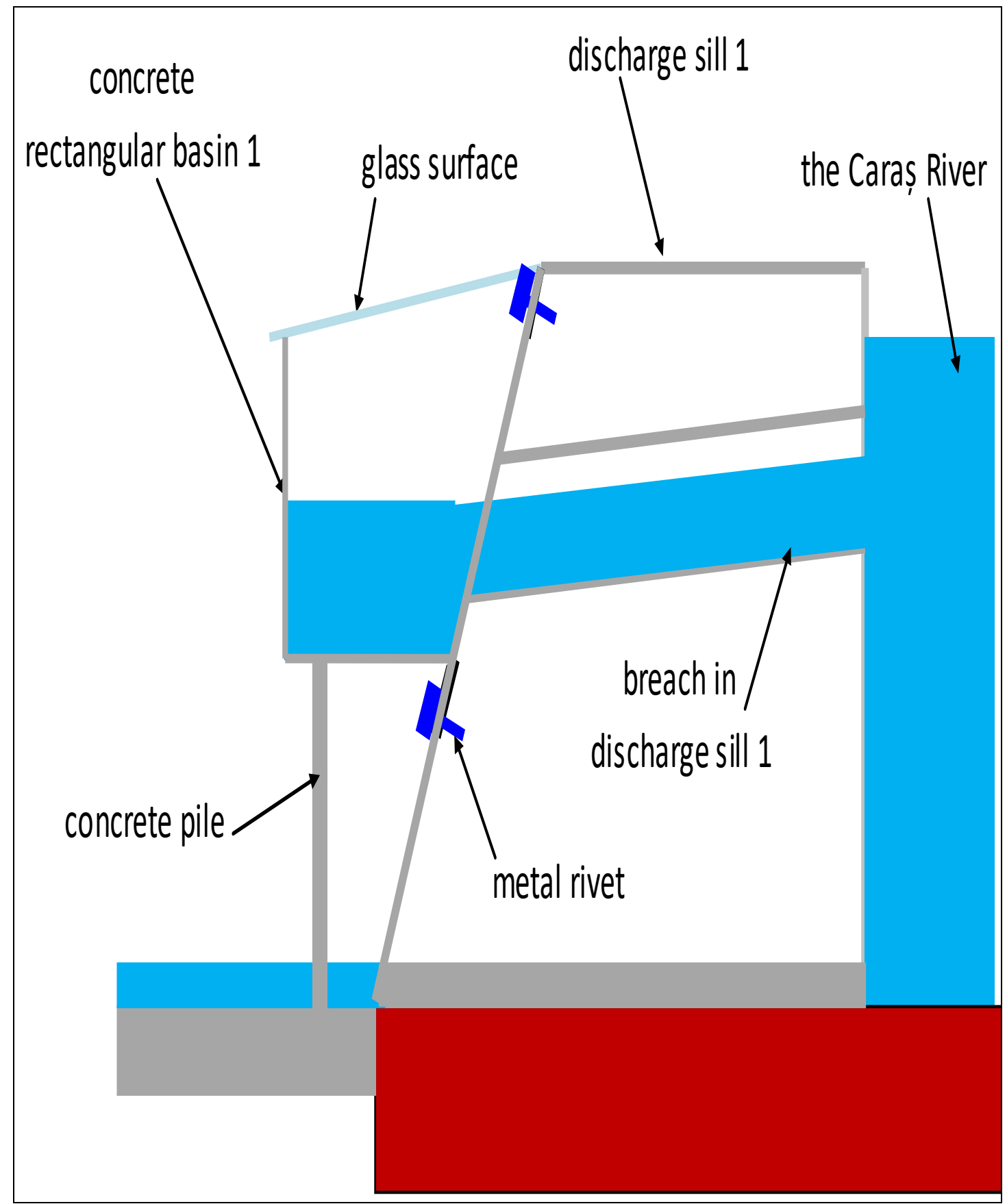

Figure 7: Positioning of the rectangular basin - indicative scheme.

The parallelipipedic basin will have on its surface a crenel with the same dimensions as the breach in threshold 1 (60 cm height, width $40 \mathrm{~cm}$ ) (Fig. 8). Ensuring the breaches have identical dimensions will ensure a consistent discharge through the new channel. 


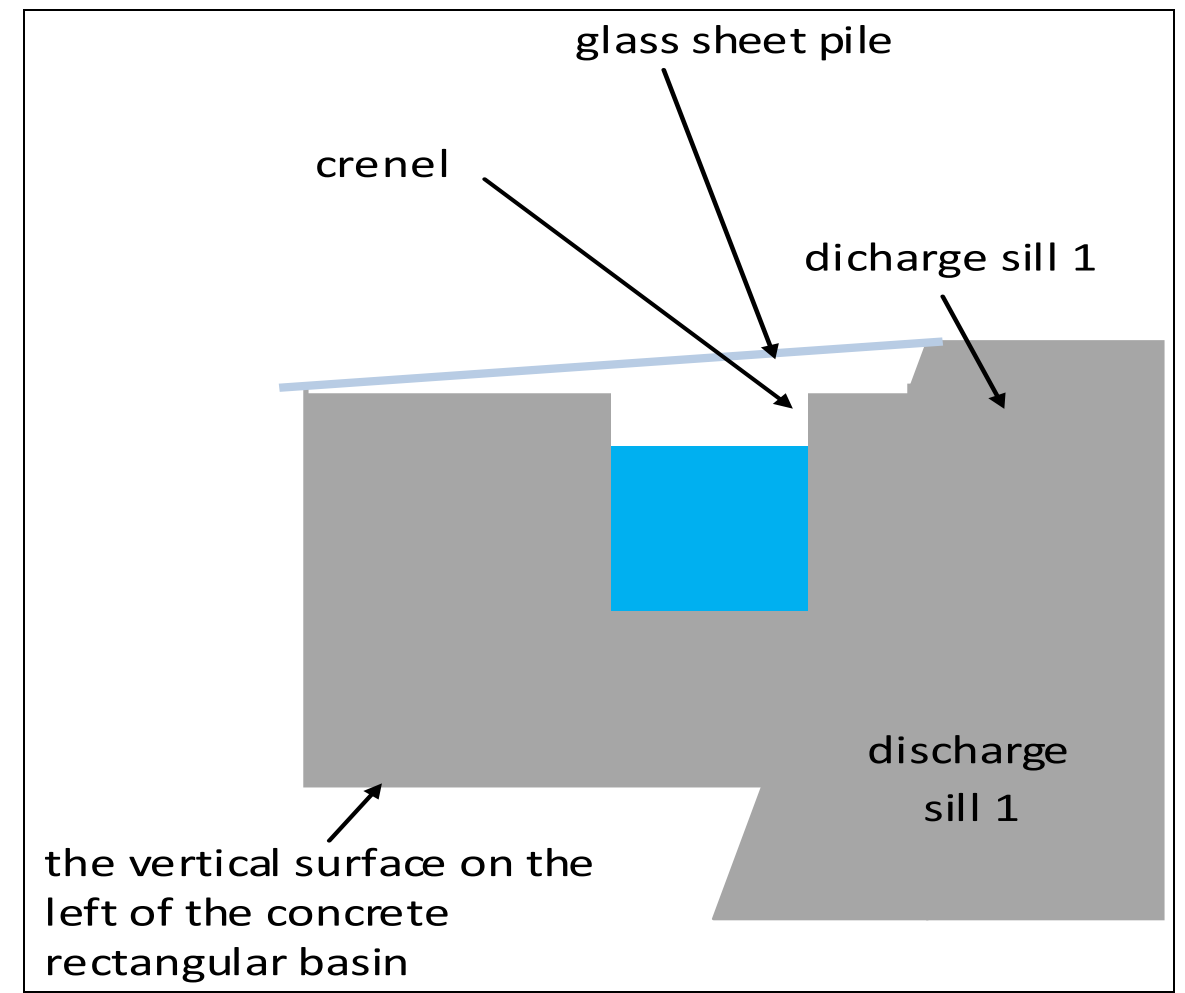

Figure 8: Positioning the crenel in the rectangular basin - indicative scheme.

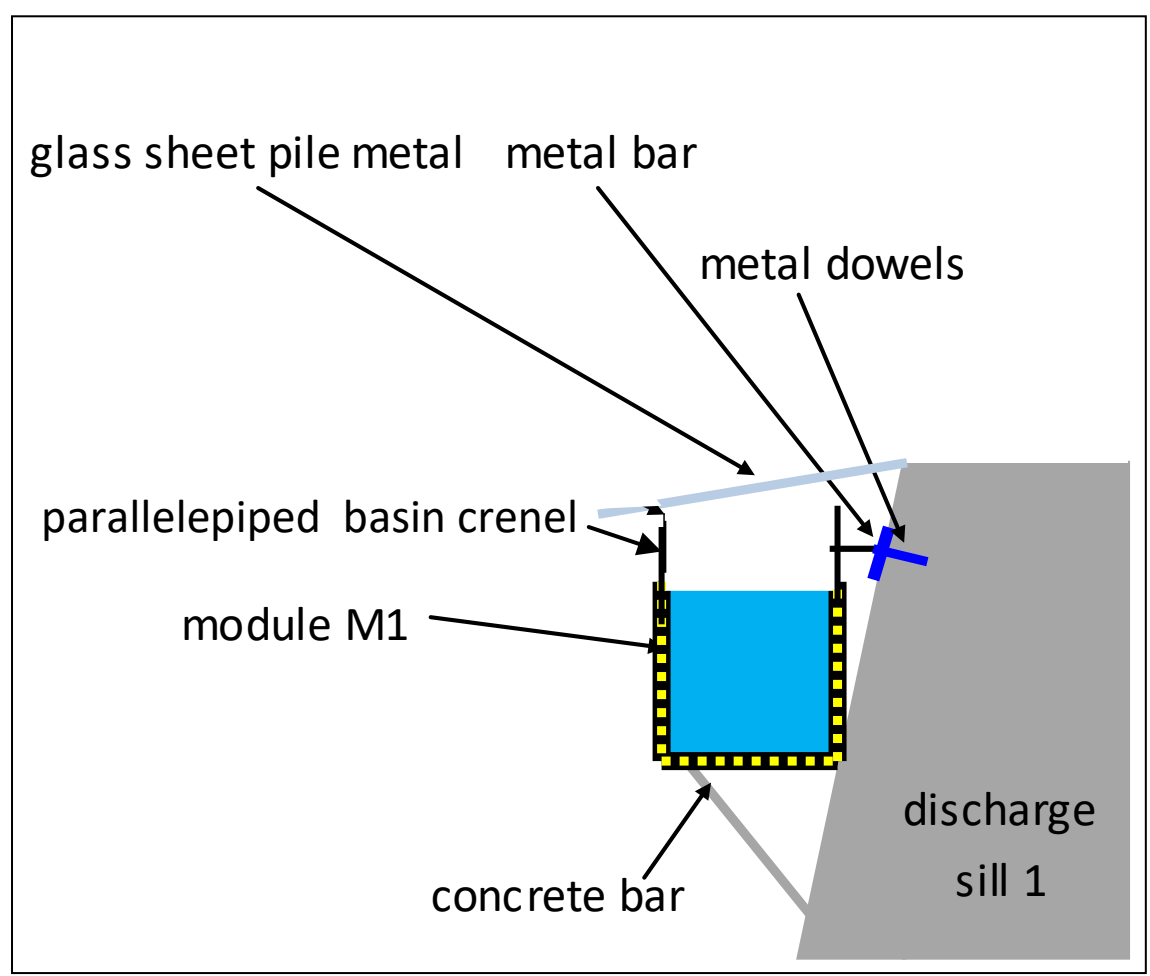

Figure 9: Positioning the rectangular channel in relation to discharge sill 1 - indicative scheme. 


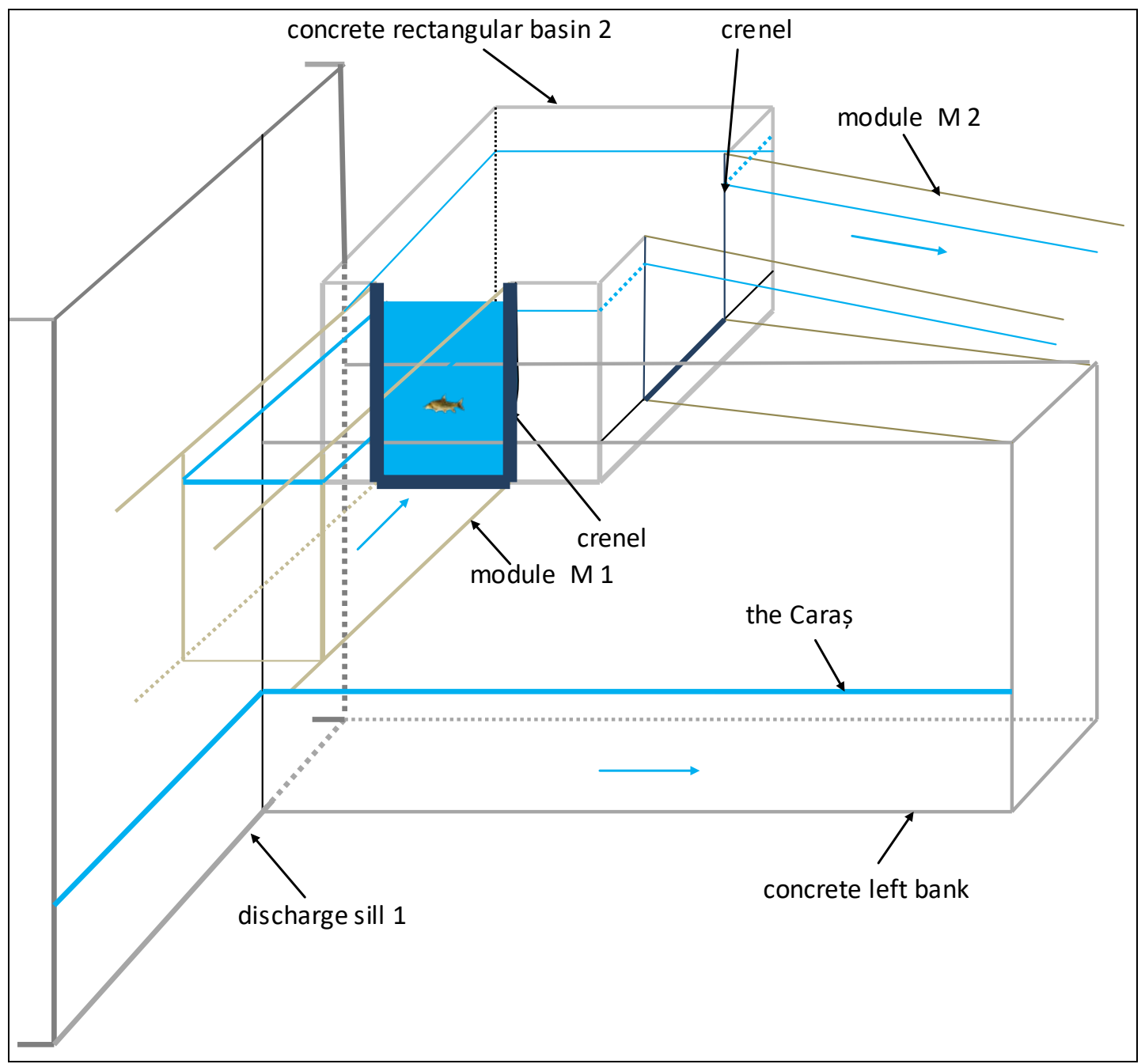

Figure 10: Positioning the second resting basin for fish fauna - indicative scheme.

The rectangular basin 2 (resting pool), which has the role of connecting the M1, M2 and the two rectangular basins ( 1 and 2 ), also has a second crenel with the dimensions of the first crenel and the channel dimensions (Module 1). From crenel 2, another channel (Module 2) with the same dimensions as Mod 1 would be installed. Module 2 will extend until the end of the left concrete streambank perhaps tangentially (depending on the slope module). Another rectangular basin 3 (resting pool) will be attached to the concrete left streambank and connected with the M2 module and to the M3 module by another crenel. The crenel will be fixed to the basin 3 by a metal bar which is fixed in two bearings (Fig. 11). Module 3 is formed from two variable geometry modules M3 a and M3 b that can be folded in the event of a flood. The bearings fixed by the basin 3 help to raise the M3a with of a metallic cable with a manual winch or an electric winch set in motion by a level sensor (Fig. 12). 


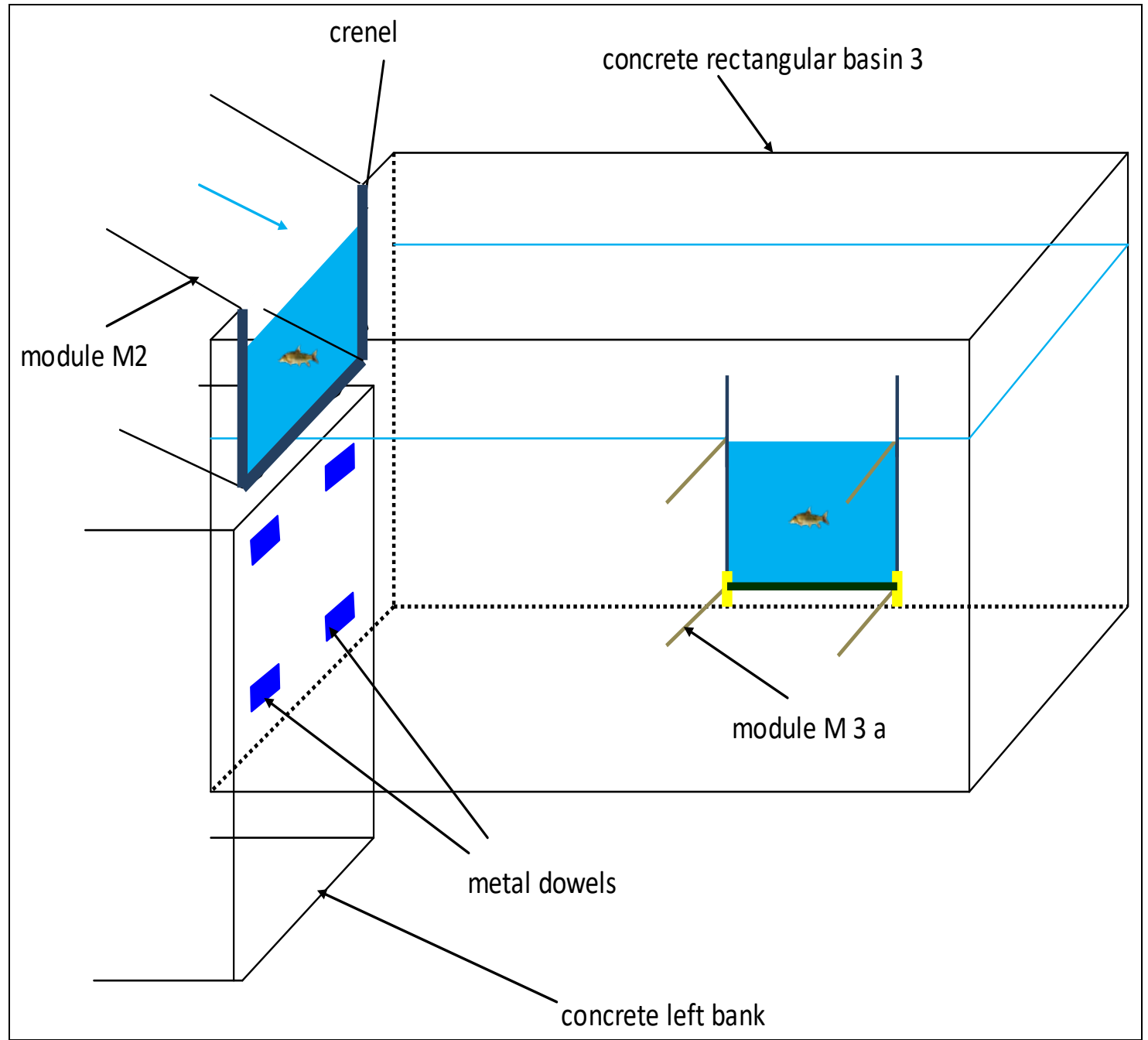

Figure 11: Positioning the second resting basin for fish fauna - indicative scheme. 


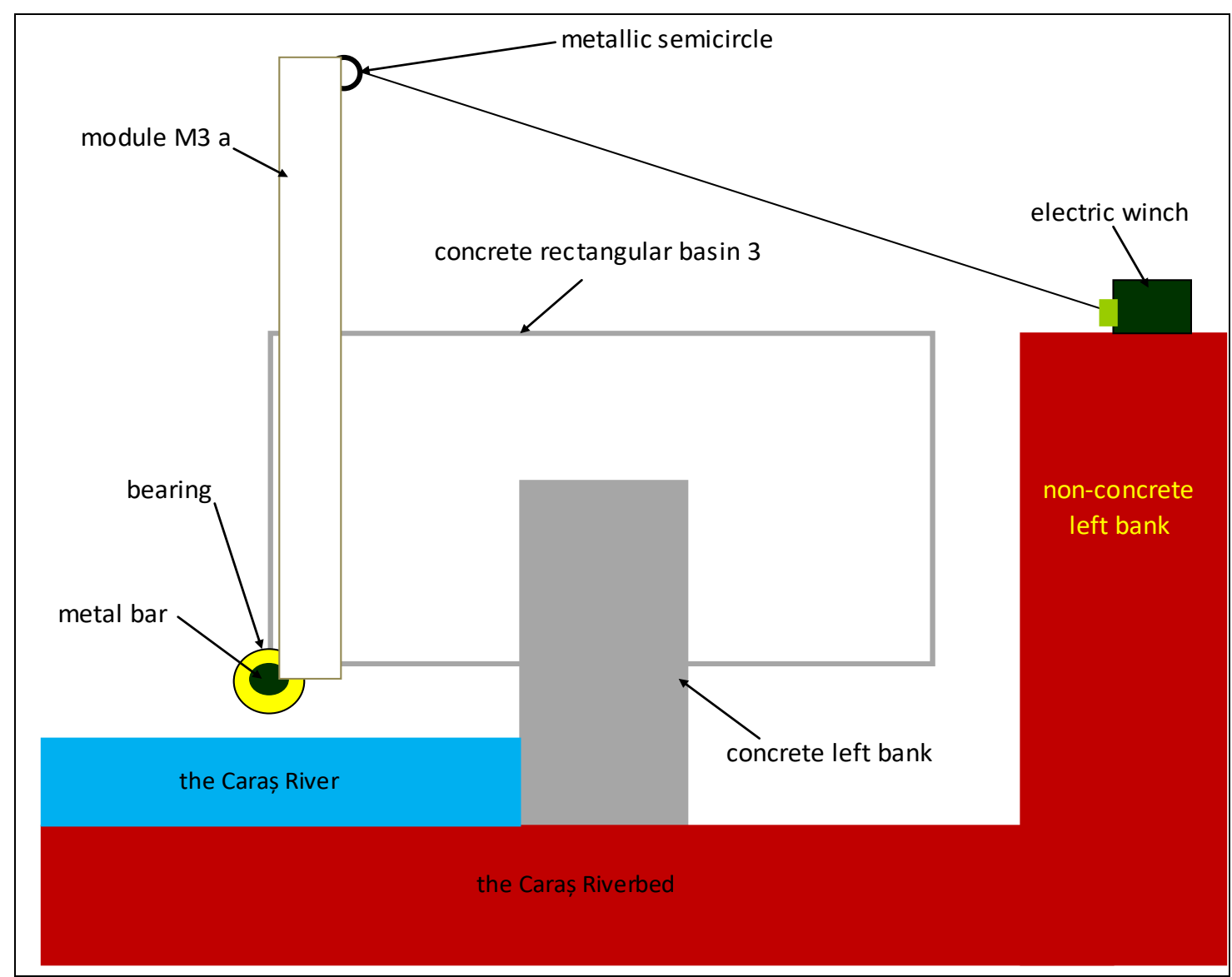

Figure 12: Positioning the electric winch and the metal cable - indicative scheme.

Module 3 will be supported by a single concrete pillar (Fig. 12) and will reach the right bank where the water will be discharged into a rectangular concrete basin 4 (Fig. 13). Rectangular basin 4 will have variable geometry. The basin can be fixed into place by an electric or manually winch equipped with a cable attached to the upstream end of the M3 b module. The point of this section being movable is to ensure that functionality can be maintained under a range of river flows. However, it will require a staff member to manually change the fish pass configuration when river flows change; but will ensure that fish can pass under a range of different flow conditions.

A rectangular semibasin will then be fixed at the end of each two M3a and M3b modules. When swinging on the inclined plane (linear system for fish migration), the two semibasins will align and form one basin of galvanized metal sheet piles of $1.5 \mathrm{~cm}$ thickness (Fig. 14). If the two modules do not have variable geometry, floods on Caraș River may destroy them. As such, we offer a design solution here that will enable the channel to pass more flows under high discharge, and lower flows under low discharge, this protecting the integrity of the system and maximising fish passage opportunities during different river discharges. 


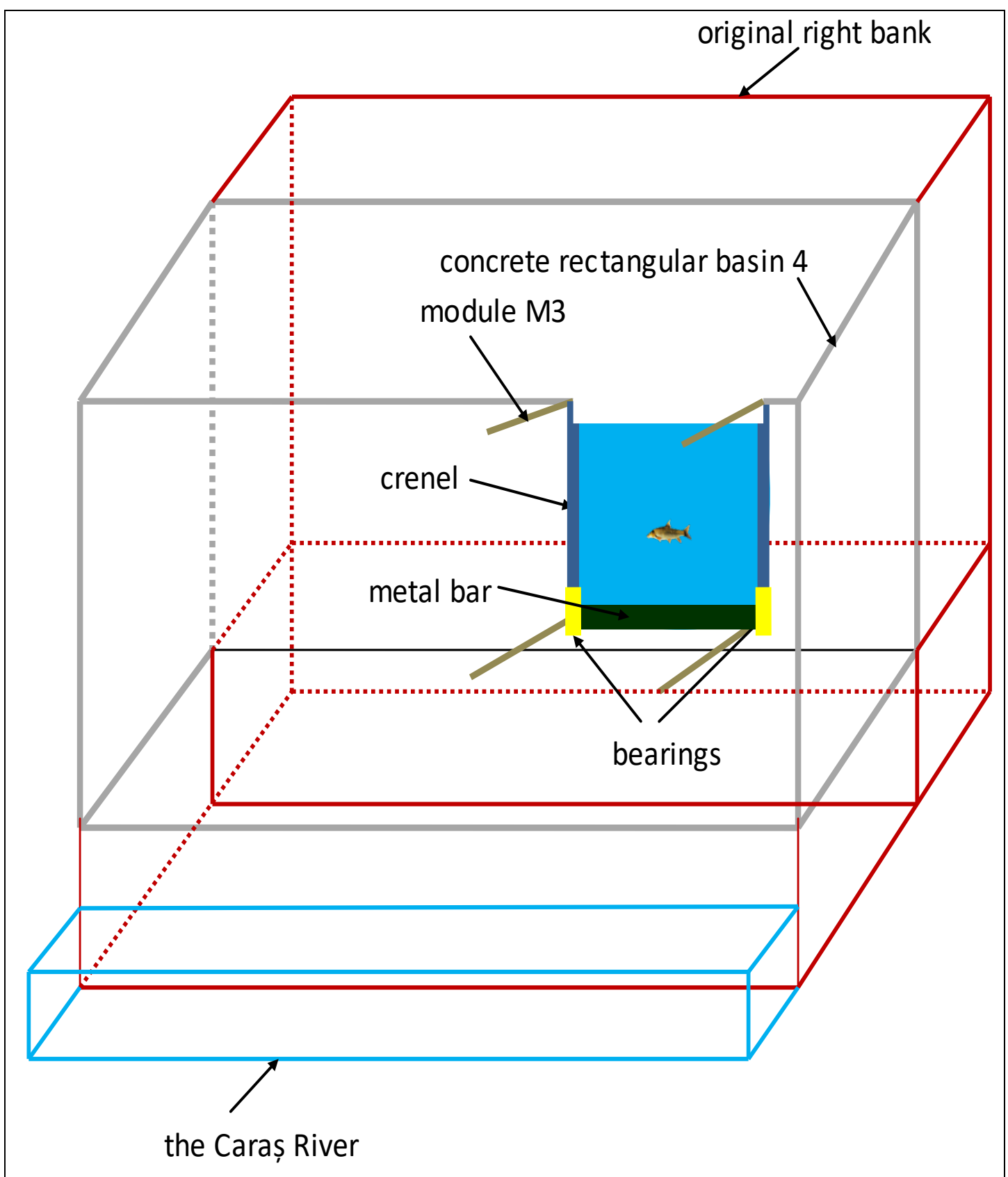

Figure 13: Positioning module M3b in the rectangular concrete basin 4 situated in the right bank - indicative scheme. 


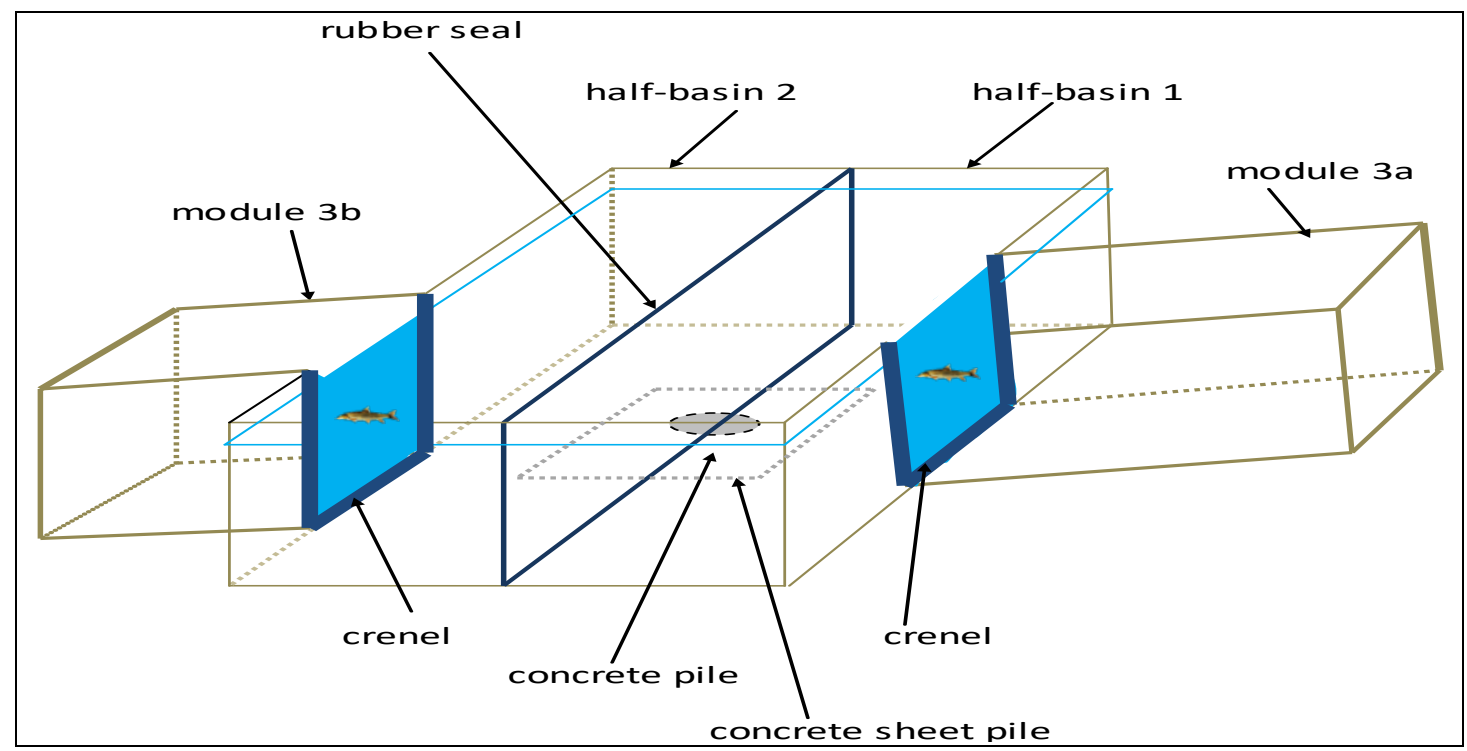

Figure 14: Achieving a resting basin for fish fauna made of two basins - indicative schemes.

The entire system would require a concrete slab (Fig. 14) to support the basin formed by the two semibasins.

This rectangular concrete basin 4 will be directly connected by a crenel with two connection basins with five $\mathrm{cm}$ hydraulic jump. If the fishway gradient is set to mimic the natural slope of the river, then a five cm hydraulic jump is well within the limits of swimming abilities as reported in other studies of salmonid swimming ability. So both adult and juvenile species should be able to ascend. The last basin connects directly into the Caraş River (Fig. 15). The connecting basins are also made of concrete sheet piles.

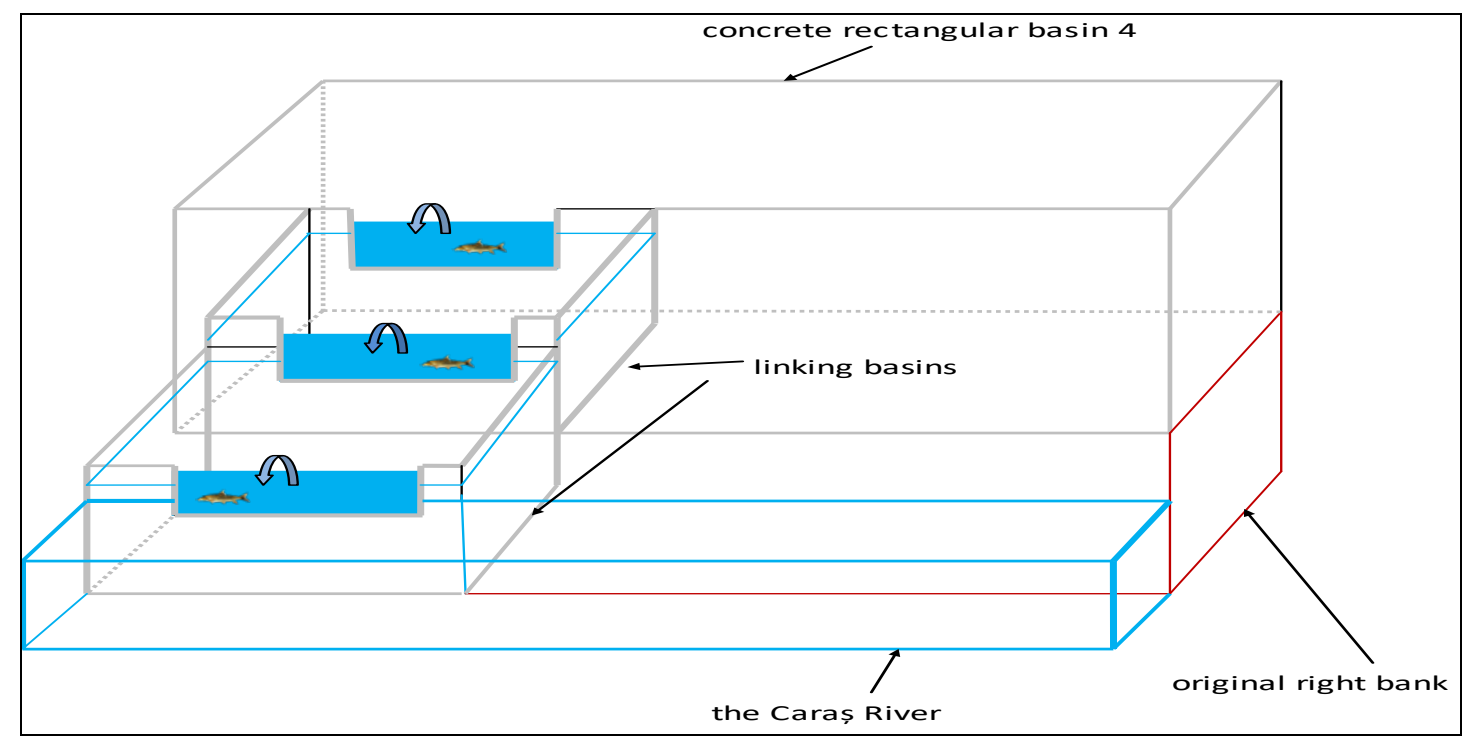

Figure 15: Positioning the linking basins - indicative scheme. 


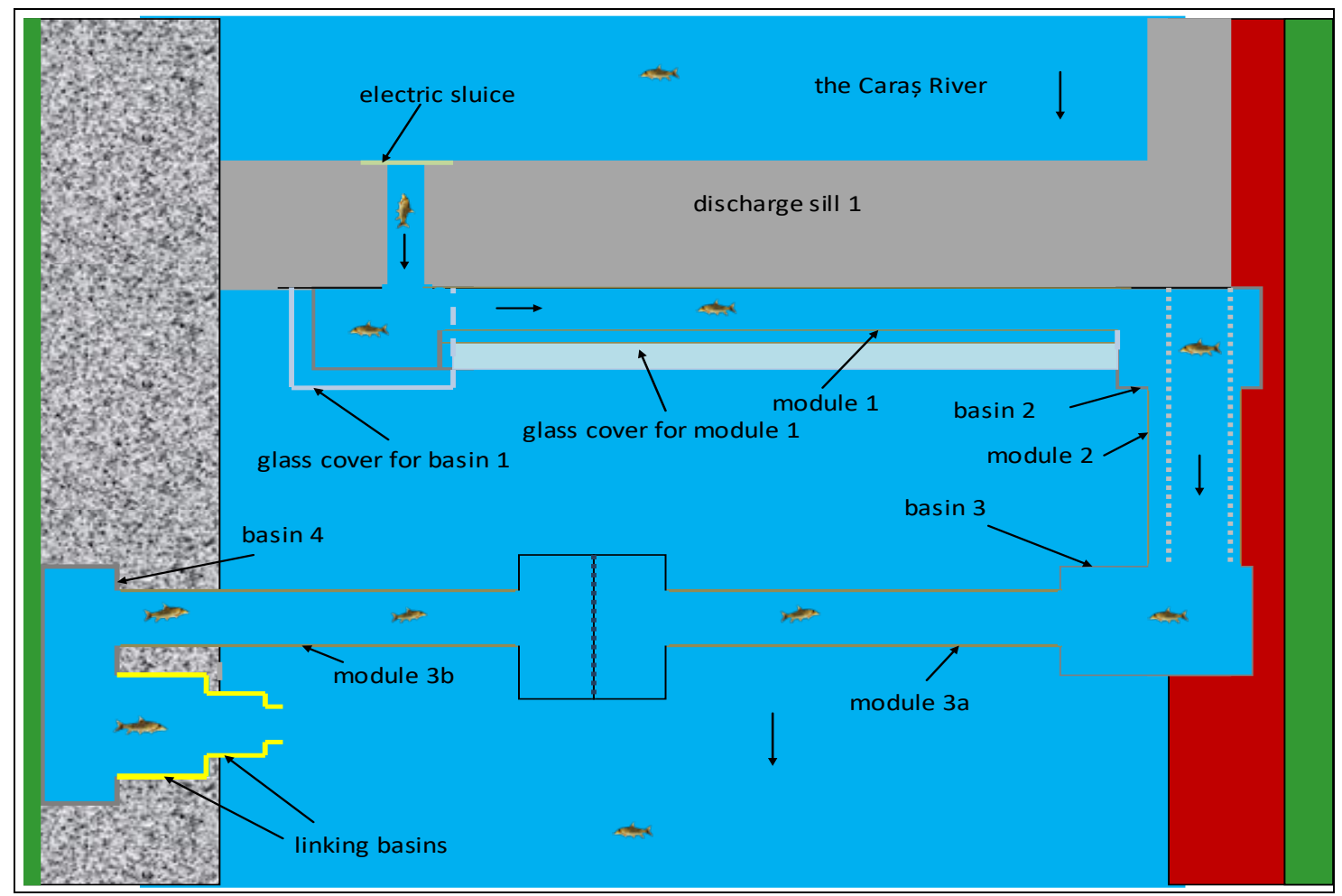

Figure 16: The general scheme of the fish migration system, upstream-downstream of the first discharge sill - indicative scheme.

\section{CONCLUSIONS}

Essentially the design we propose is a retrofitted pool and weir fish pass. The main aim of this structure is to allow displaced salmonids to recolonise upstream sections following flooding events (Bănărescu, 1964). In recent times such events happen more frequently when floods emerge from a significant gorge (Bănăduc et al., 2013). By retrofitting a channel to thresholds on the existing weir, we can avoid costly de-watering and coffer damming and only require a small breach of the existing weir structure. It will maintain the integrity of the existing weir and also ensure that the fishway entrance is appropriately placed to maximise fish movements. Importantly, for much of the time all river flow would be directed through the structure by way of existing pipes, thus providing sufficient attractant flow to allow fish to enter the structure.

This proposed technical solution for fish movement over the spill thresholds is entirely based on directing the flow of water to create attraction that provides suitable hydraulic conditions for fish. This system mimics other successful pool and weir designs but has the added benefit of being easily detachable from the spill threshold if required, resistant to corrosion and will provide benefits to fish if internal hydraulic complement fish swimming abilities. Matching the fish pass slope to the overall river gradient should further ensure that both adults and juveniles can pass. Ensuring the fish pass can operate within a head water level variation of one meter will ensure that the need for human intervention to operate the winches would be minimal. As such, understanding the local hydrology would be needed to ensure the final design is grounded within the operational boundaries. 
We stress that the solution should be applied within the context of whole-of-system planning. We have focused on only the most downstream barrier in the system, but functional fish passes will be needed on the upstream barriers as well. Such an approach is essential to ensure that all upstream habitats are made available to fish over the long term. It will allow free movement between the Caraş River gorge sectors and the lower ones and other tributaries in the system.

Finally, we stress the need that the construction of any fish ladder must be accompanied by a robust monitoring program to demonstrate that the proposed solution is effective. Any shortcomings can then be repaired and what we learn applied to other sites so that the technology improves into the future. If applied in the context of a whole-of-catchment approach, then fish populations can be expected to improve over the long term.

\section{REFERENCES}

1. Aadland L. P., 1993 - Stream habitat types: their fish assemblages and relationship to flow, North American Journal of Fisheries Management, 13, 790-806.

2. Aadland L. P., 2010 - Reconnecting rivers: natural channel design in dam removals and fish passage, Minnesota Department of Natural Resources, 15-17.

3. Barbosa F. A. R., Callisto M. and Găldean N., 2001 - The diversity of benthic macroinvertebrates as an indicator of water quality and ecosystem health: a case study for Brazil, Aquatic Ecosystem Health and Management, 4, 51-59.

4. Baxter R. M., 1977 - Environmental effects of dams and impoundments, Annual Review of Ecology and Systematics, 8, 255-283.

5. Bănăduc D., Mărginean M. and Curtean-Bănăduc A., 2013 - Geographical and human impact elements influence on the fish fauna of the Oltet River (Romania), Transylvanian Review of Systematical and Ecological Research, 15.2, The Wetlands Diversity, Edit. Universităţii "Lucian Blaga" din Sibiu, ISSN 1841-7051, 9-44.

6. Bănăduc D., Rey Planellas S., Trichkova T. and Bănăduc A., 2016 - The lower Danube RiverDanube Delta-North West Black Sea: a pivotal area of major interest for the past, present and future of its fish fauna - A short review, Science of the Total Environment, 545-546, 137-151.

7. Bănărescu P. M., 1964 - Fauna R. P. Române, Pisces-Osteichthyes, XIII, Edit. Academiei Române, 959. (in Romanian)

8. Bunn S. E. and Arthington A. H., 2002 - Basic principles and ecologic consequences of altered flow regimes for aquatic biodiversity, Environmental management, 30, 4, 492-507.

9. Fischer P. and Cyffka B., 2014 - Floodplain restoration on the upper Danube by re-establishing back water dynamics: first results of the hydrological monitoring, Erdkunde, 68, 1.

10. Ghinea D., 2002 - Enciclopedia geografică a României, Edit. Enciclopedică, Bucureşti, 1456.

11. Katopodis C., 1990 - Advancing the art of engineering fishways for upstream migrants, Proceedings of International Symposium on Fishways, Gifu, Japan, 19-28.

12. Kay E. L. and Voicu R. 2013 - Developing an ecological and migration system for ichthyofauna on the Crişul Repede River near the City Hall of Oradea, Management of Sustainable Development, Sibiu, Romania, 5, 2, 27-33.

13. Kemp P. S. and O'Hanley J. R., 2010 - Procedures for evaluating and prioritising the removal of fish passage barriers: a synthesis, Fisheries Management and Ecology, 297-322.

14. Larinier M., 1983 - Guide pour la conception des dispositifs de franchissement des barrages pour les poisons, Bulletin Français de la Peche et de la Pisciculture, 56, 1-39. (in French)

15. Lenhardt M., Jarić I., Kolarević S., Vuković-Gaćic B., Knezević-Vukčević J., Smedereva-Lalić M., Cvijanović G. and Gaćic Z., 2016 - Impact of human activities on the status of the Danube River in Serbia: microbiological and ichthyofaunistic studies, Acta Oecologica Carpatica, IX, $151-176$. 
16. McKay S. K., Cooper A. R., Diebel M. W., Elkins D., Oldford G., Roghair C. and Wieferich D., 2016 - Informing watershed connectivity barrier prioritization decisions: a synthesis, River Research and Applications, 33, 6, 847-862.

17. Nechifor R., Popa G.-O., Samu M., Dudu A., Bănăduc D., Costache M. and Georgescu S. E., 2017 - The genetic profiles of two salmonid populations from Romania obtained through nuclear markers analysis, Animal Science and Biotechnologies, 50, 1, 74-78, ISSN: 2049-1891.

18. O’Doherty G., 2009 - ADF and G fish passage program: summary of existing inventory and assessment data and gap analysis, September, Special Publication, 10-17.

19. Popa G.-O., Khalaf M., Dudu A., Curtean-Bănăduc A., Bănăduc D., Georgescu S. E. and Costache M., 2013 - Brown trout's populations genetic diversity using mitochondrial markers in relatively similar geographical and ecological conditions - a Carpathian case study, Transylvanian Review of Systematical and Ecological Research, 15.2, The Wetlands Diversity, Edit. Universităţii “Lucian Blaga” din Sibiu, ISSN 1841-7051, 125-132, 2013.

20. Popa G.-O., Curtean-Bănăduc A., Bănăduc D., Florescu I. E., Burcea A., Dudu A., Georgescu S. E. and Costache M., 2016 - Molecular markers reveal reduced genetic diversity in Romanian populations of Brown Trout, Salmo trutta L., 1758 (Salmonidae), Acta Zoologica Bulgarica, 68, 3, 399-406, ISSN 0324-0770.

21. Posea G. (coord.), 1982 - Enciclopedia Geografică a României, Edit. Ştiinţifică şi Enciclopedică, Bucureşti, 847. (in Romanian)

22. Sedeño-Diaz J. E. and López-López E., 2009 - Aquatic health assessment: a methodological proposal for Mexican aquatic ecosystems, Transylvanian Review of Systematical and Ecological Research, 8, The Wetlands Diversity, 201-214.

23. Sommerwerk N., Bloesch J., Paunović M., Baumgartner C., Venohr M., Schneider-Jacoby M., Hein T. and Tockner K., 2010 - Managing the world's most international river: the Danube River basin, Marina and Freshwater Research, 61, 7, 736-748, doi.org/10.1071/MF09229.

24. Voicu R. and Merten E., 2014 - Creating a system for upstream-downstream fish migration over the first and the second discharge sills downstream of Mănăştur dam on the Someşul Mic River (Cluj Napoca, Transylvania, Romania), Transylvanian Review of Systematical and Ecological Research, 16, 2, The Wetlands Diversity, 163-182.

25. Voicu R. and Breţcan P., 2014 - Solution for fish migration on the Someşul Mic River upstream downstream of Mănăştur dam in Cluj Napoca, Annals of Valahia University of Târgovişte, Geographical Series, 14, 1, 125-132.

26. Voicu R. and Baki P., 2017 - Improving upstream and downstream fish passage at Retiş dam on Hârtibaciu River - Sibiu County (Transylvania), Annals of Valahia University of Târgovişte, Geographical Series, 17, 1, 47-57.

27. Voicu R., Costescu C., Voicu L. and Lengher-Bica N., 2015 - Solution for ichthyofauna migration upstream-downstream of the two spillways located near Mănăştur dam on the Someşul Mic River in the Cluj Napoca City (România), Lakes, reservoirs and ponds, 9, 1, 43-55. 